\title{
THE EFFECT OF PIGMENTS UPON THE CONSTANTS OF LINSEED OIL.
}

\author{
BY \\ HENRY A. GARDNER, \\ Assistant Director, The Institute of Industrial Research, Washington, D. C.
}

WHEN sealed packages of paints of the cheaper grades are opened after having been stored for a considerable length of time, there is occasionally observed a degree of hardness that renders application difficult. The user is generally at a loss to account for such a condition, inasmuch as the modern metal container is air-tight and has but little room for improvement. The cause of the hardening that has taken place may therefore be assumed to result from certain reactions between the different constituents of the paint. There can be no doubt but that certain kinds of pigments have some influence in the reactions that result in hardening, but the responsibility has been too often placed entirely with the pigment portion of paints. That the oil or vehicle part may have an even more profound relation to the trouble has not been given the consideration it deserves. In support of this statement there is presented herewith evidence of an important nature, in the form of results obtained from the tests described below:

Nearly two years ago the writer carefully prepared a series of paints from various well-known pigments, using as a grinding medium a standard vehicle of pure linseed oil containing neither drier nor thinner of any type. The amount of oil used with each pigment was sufficient to bring the paints in every case to a relative viscosity or body, which was somewhat heavier than is ordinarily used in the application of paints to wooden or metal surfaces. These paints, after preparation, were carefully placed in friction-top tin containers. They were moved about occasionally and were subjected to shipment by freight on two occasions, finally remaining on a shelf in the writer's laboratory for nearly a year previous to examination. Upon removing the lids from the cans there was evidenced, by the appearance of some of the paints, a considerable change of a chemical nature. The writer, attrib- 
uting the change that had taken place to a form of saponification, or rather hydrolysis, as such action may be properly termed in the case of paints, was impressed with the opportunity of examining the oil content of the paints, in order to determine whether any marked change had occurred in the constants of the pure linseed oil which was used in their grinding. Fortunately, there was on record the analysis of the oil which had been used for this purpose. The paints were therefore placed individually in twoquart glass jars with a large quantity of a solvent mixture made of $90^{\circ}$ benzol and $86^{\circ}$ petroleum ether. After the pigment content of the paint had settled out by gravity, the solvent containing the oil in solution was removed by a syphon and subjected to distillation. The temperature of distillation was kept at a point sufficiently high to remove the low boiling point solvent, but not high enough to affect the oil residue. The usual method of oil examination was then followed, many of the determinations being made in duplicate. The results of these tests are given below.

RESULTS OF EXAMINATION OF OILS EXTRACTED FROM PAINTS.

Analysis of oil used in grinding and thinning paints:

Specific gravity $\ldots \ldots \ldots \ldots \ldots \ldots \ldots \ldots \ldots \ldots, \quad .932$

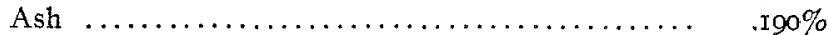

Iodine No. $\ldots \ldots \ldots \ldots \ldots \ldots \ldots \ldots \ldots \ldots$ I8I.

Acid value $\ldots \ldots \ldots \ldots \ldots \ldots \ldots \ldots \ldots \ldots, 2.5$

TEST NO. I.

Zinc Oxide.

Condition on Opening.-Paint in excellent condition. Very soft. Some oil of light color floating on top. After extraction with solvent the oil contained fine white zinc of a colloidal nature, which separated out only after several days' standing.

Analysis of extracted oil:

Specific gravity ............... . 9237

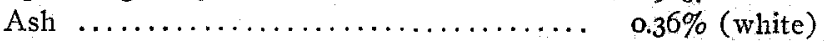

Iodine No. ................... 16ז.

Acid value $\ldots \ldots \ldots \ldots \ldots \ldots \ldots \ldots \ldots, 3.5$ 
TEST NO. 2.

Corroded White Lead (Basic Carbonate-White Lead).

Condition on Opening.-Paint had thick, wrinkled skin on top, but was in very fair condition. Oil, after extraction, was light colored and clear.

Analysis of oil:

Specific gravity $\ldots \ldots \ldots \ldots \ldots \ldots . \quad .9372$

Ash $\ldots \ldots \ldots \ldots \ldots \ldots \ldots \ldots \ldots \ldots \ldots$ I.I $49 \%$ (light yellow)

Iodine No. ................. 157.5

Acid value $\ldots \ldots \ldots \ldots \ldots \ldots \ldots . \quad 8.6$

TEST NO. 3 .

Leaded Zinc.

Condition on Opening.-Paint in very good condition. Considerable oil floating on top. Oil, after extraction, was somewhat cloudy, but cleared up after settling for twenty-four hours.

Analysis of oil:

Specific, gravity $\ldots \ldots \ldots \ldots \ldots \ldots \ldots \ldots . \quad .9389$

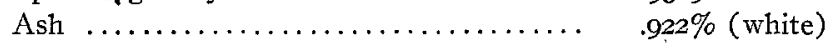

Iodine No. ...................... I57.4

Acid value $\ldots \ldots \ldots \ldots \ldots \ldots \ldots \ldots \ldots, \quad 5.7$

TEST NO. 4.

Corroded White Lead (Basic Carbonate-White Lead) ... $50 \%$ Zinc oxide $\ldots \ldots \ldots \ldots \ldots \ldots \ldots \ldots \ldots \ldots \ldots, 40 \%$ Barytes $\ldots \ldots \ldots \ldots \ldots \ldots \ldots \ldots \ldots \ldots \ldots \ldots \ldots \ldots \ldots$ 10 $\%$

$100 \%$

Condition on Opening.-Paint in excellent condition. Some oil floating on top.

Analysis of oil:

Specific gravity

Ash

$.674 \%$ (light yellow)

Iodine No. ............... I54.I

Acid value $\ldots \ldots \ldots \ldots \ldots \ldots \ldots \ldots .6 .7$ 
TEST NO. 5 .

Sublimed white lead (basic sulphate-white lead) .....60\%

Zinc oxide

Condition on Opening.-Paint in excellent condition. Some oil floating on top.

Analy'sis of oil:

Specific gravity ............... .9334

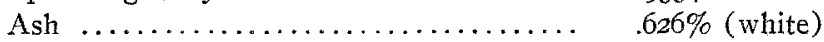

Iodine No. ...................... I57.8

Acid value $\ldots \ldots \ldots \ldots \ldots \ldots \ldots \ldots \ldots .5 .6$

\section{TEST NO. 6. \\ Barytes (Barium Sulphate).}

Condition on Opening.- - Paint settled to a considerable extent. Much clear oil floating on top.

Analysis of oil:

Specific gravity $\ldots \ldots \ldots \ldots \ldots \ldots \ldots \ldots . . .9325$

Ash $\ldots \ldots \ldots \ldots \ldots \ldots \ldots \ldots \ldots \ldots \ldots \ldots \ldots \ldots . .212 \%$ (light)

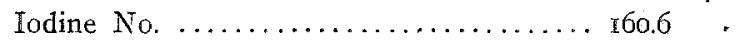

Acid value $\ldots \ldots \ldots \ldots \ldots \ldots \ldots \ldots \ldots, 3.5$

\section{TEST NंO. 7 .}

Silica.

Condition on Opening.-Heavy, viscous oil, resembling a varnish, was floating on a partly-settled mass of pigment. After extraction, the oil held some finely-divided pigment in suspension for some time.

Analysis of oil:

Specific gravity ..................... .9465

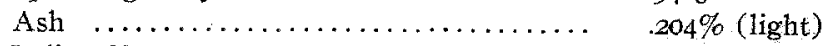

Iodine No. ..................... I49.2

Acid value $\ldots \ldots \ldots \ldots \ldots \ldots \ldots \ldots, 8.7$

TEST NO. 8.

American Vermilion (Basic Chromate of Lead).

Condition on Opening.-Pigment settled very hard. Oil, after extraction, was dark, but clear. 
Analysis of oil:

Specific gravity $\ldots \ldots \ldots \ldots \ldots \ldots \ldots \ldots, \quad .939$

Ash $\ldots \ldots \ldots \ldots \ldots \ldots \ldots \ldots \ldots \ldots \ldots \ldots \ldots$ r. $.271 \%$ (yellow)

Iodine No..................... $\quad \mathrm{I}_{56.7}$

Acid value $\ldots \ldots \ldots \ldots \ldots \ldots \ldots \ldots, \quad 8.3$

TEST NO. 9 .

Red Lead.

Condition on Opening.-Pigment settled very hard. A thick, - gelatinous oil floating on top of pigment. Oil, after extraction, was dark brown in color.

Analysis of oil:

Specific gravity

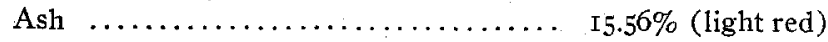

Iodine No. .................... 135.4

Acid value $\ldots \ldots \ldots \ldots \ldots \ldots \ldots \ldots, \quad 19.2$

TEST NO. IO.

Iron Oxide.

Condition on Opening.- In excellent condition. Very soft, smooth paste. After extraction, the oil was clear, but of a dark red color.

Analysis of oil:

Specific gravity ...................... $\quad .9457$

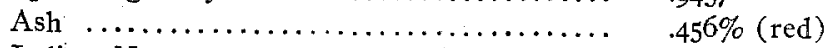

Iodine No. ...................... 156.3

Acid value $\ldots \ldots \ldots \ldots \ldots \ldots \ldots \ldots \ldots, 8,6$

TEST NO. II.

Carbon Black.

Condition on Opening.--Thin, wrinkled skin on surface. Paste below skin, very soft and smooth. After extraction, the oil was clear and of light color.

Analysis of oil:

Specific gravity $\ldots \ldots \ldots \ldots \ldots \ldots \ldots \ldots \ldots . \quad .9356$

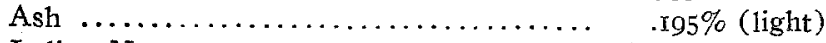

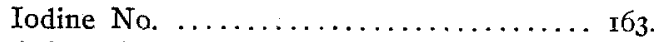

Acid value $\ldots \ldots \ldots \ldots \ldots \ldots \ldots \ldots \ldots, 10.5$ 
TEST NO. I2.

Graphite.

Condition on Opening.-Very soft and smooth paste. After extraction, the oil was clear and light in color.

Analysis of oil:

Specific gravity $\ldots \ldots \ldots \ldots \ldots \ldots \ldots \ldots \ldots \ldots$

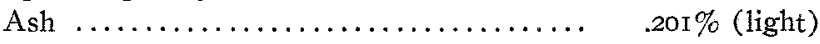

Todine No. ...................... 158.5

Acid value $\ldots \ldots \ldots \ldots \ldots \ldots \ldots \ldots$ I 3.3

These results show that inert pigments such as barytes, iron oxide, graphite and carbon black do not enter into chemical action with linseed oil; the percentage of ash found in the oil extracted from the above pigments being practically identical with the percentage shown by the raw oil. That such pigments may, however, have some physical action upon the oil, that will later develop a chemical change therein, seems evident. The thickened condition of the oil extracted from the silica paint, and the low iodine values and high acid values shown by all of the oils extracted from the above-mentioned inert pigments, would give credence to the above statement.

The pigment that is ordinarily termed American vermilion, the true form of which is a basic chromate of lead, seems to have had no very marked effect upon the oil in which it was ground. It would seem, therefore, that it would prove quite practical to transport this pigment in paste form. On account of its value as a protective of metal, it will probably replace, to some extent, the use of red lead for priming steel. The pigment red lead had a marked hydrolyzing reaction on the oil in which it was ground. The latter contained a very large percentage of lead linoleate, free fatty acid, and glycerin. The iodine number of this oil was lower than that of any other extracted. It is, of course, well known that red lead, on account of its tendency to harden in the package, is seldom put up in mixed form. The dry pigment is generally mixed with oil just before application, from 30 to 35 pounds of pigment to a gallon of oil being the proper consistency for painting.

Zinc oxide and zinc lead had but slight action with the oil, while basic carbonate-white lead showed somewhat greater action, 
but not sufficient to be of any detriment. With paints containing mixtures of lead and zinc pigments only slight action was shown. The perfect condition of these paints indicates that any properlyprepared combination pigment paint may be safely stored in cans for long periods without bad effects, provided the oil used is of normal grade.

The most astounding change shown in the tests was that in the iodine values of the oils extracted from all of the paints. It would appear, therefore, that when paints are stored for a considerable period of time and then examined for the iodine value of their oil content a lowering of the iodine value should not constitute cause for rejection or be sufficient evidence to state that the oil was adulterated with oils of lower iodine value. Cognizance of this statement should be given by railroads and purchasing corporations which have adopted specifications for oil paints.

As is well known, linseed oil is a mixture of tri-glycerides of fatty acids. In other words, fatty acids are combined with glycerin in the proportion of three equivalents of acid to one equivalent of glycerin, the latter material acting as a tri-atomic alcohol or base. The fatty acids in linseed oil, among which may be mentioned oleic acid, are of an unsaturated nature, being capable of taking up large quantities of oxygen. The combination of these fatty acids with glycerin may be effected by certain enzymes which exist in the seed of the plant. Moreover, the resolution of such compounds with a consequent breaking away of the acids, from the glycerin, to a free condition, may be accomplished by enzymes which have hydrolyzing properties. This splitting-up reaction may also be effected by several methods of a chemical nature. The hydrolyzing effect of moisture is sometimes of considerable moment and is probably responsible to some degree for the small percentage of free fatty acid which is generally present in all linseed oils. That some oils have higher acid values than others is well known, the acid refined oils being especially high in free acid; treatment with various mineral acids accelerating hydrolysis. The most rapid form of hydrolysis is effected with strong bases such as soda, the ultimate products being water-soluble soda soaps and glycerin. When the hydrolyzing base is a relatively insoluble product and of a metallic nature such as litharge, 
the hydrolysis of the oil is slow and only partial, there being formed a water-insoluble lead soap, glycerin, and some free fatty acid.

When hydrolysis has taken place in a paint, considerable thickening is observed. In the tests which are charted above it will be observed that the most extravagant example of hydrolysis was shown by the red lead paint. The oil from this paint showed over 15 per cent. of inorganic lead compounds in the ash. It will also be noticed that the oil had become very acid in nature and had the appearance of a thick jelly, which may be accounted for by the large percentage of glycerin present. Although the red lead paint was very thick, difficult to break up, and too heavy for brushing, it was not really hard. The writer has had occasion, however, to examine several samples of paint recently which were very much harder than the red lead, one, in fact, being so hard that a knife was required to make any impression upon its solidified surface. These paints, moreover, contained pigments of a basic nature, containing a very high percentage of lead and zinc. An examination of the oil in which these paints were ground showed acid values ranging from 8 to $I 6$. That the reaction of the free acid upon the pigments was the real cause of the hardening of the paint was the writer's conclusion. 'A series of tests were therefore made, in which was included the treatment of paints with small percentages of free oleic acid, one of the most prominent constituents found in oils of a high acid value. There were also included tests in which paints were treated with sulphites, there existing in the paint industry a false belief that lead and zinc pigments are apt to body and harden in oil if they contain even traces of sulphur dioxide or sulphites. Those who have held such a belief should some time examine paints made of sublimed blue lead, a pigment which contains nearly 5 per cent. of metallic sulphites and sulphides. This pigment will remain as a smooth paste in oils for months without any apparent hardening.

Small quantities of dry zinc and lead pigments (basic carbonate-white lead, basic sulphate-white lead, zinc oxide, and zinc lead) were ground in a pure raw linseed oil having a normal acid value of approximately 2.8. After standing for three days, no tendency toward hardening was shown by any of the paints. They were then divided into small portions, and to each type were 
added various materials which were under suspicion as having, when used, some contributing effect in the hardening of paint. The following table shows the results of these experiments:

Treatment with 20 per cent. gloss oil $\quad$ ( $/ 2$ rosin, $1 / 2$ benzine) .......... $\begin{aligned} & \text { Considerable hardening shown in } 24 \\ & \text { hours, indicating action between } \\ & \text { the acid rosin (resinic acids) and } \\ & \text { the basic pigments. }\end{aligned}$

$\left.\begin{array}{c}\text { Treatment with } 2 \text { per cent. sodium } \\ \text { hyposulphite } \ldots \ldots \ldots \ldots \ldots \ldots \ldots\end{array}\right\}$ No effect noticed in 6 days.

Treatment with 5 per cent. oleic acid. $\left\{\begin{array}{l}\text { Hardening occurred in two hours } \\ \text { and increased with age. Paint re- } \\ \text { sembled hard putty. }\end{array}\right.$

From these results it is apparent that oils of an acid nature are the most active cause of paint hardening. The use in cheaper paints of substitutes for linseed oil, which contain large percentages of rosin, as well as the'promiscuous use of acid rosin driers, has been the cause of the hardening of many paints. Linseed oil containing high percentages of acid is, of course, dangerous. It is evident, therefore, that a careful consideration of the vehicle portion of a paint is even more important than the pigment part, and a careful record of the acidity of paint oils should be kept by the grinder.

The author wishes to acknowledge the assistance of Messrs. L. G. Carmick and J. E. Heckel in the analytical determinations.

Nitrates from the Atmosphere in Germany. Anon. (Oil, Paint and Drug Reporter, June 24, I9I2.) - Nitrate manufactured from the air by the Norwegian and Swedish plants is slowly finding its way to the German market. It is expected that very shortly Norwegian saltpetre will be shipped in large quantities to the centres of consumption. At present the artificial nitrate is selling at 8 to 9 pfennigs more per kilo. than Chile saltpetre, but it is expected the prices will soon be equalized. In I9I I only 493.3 metric tons of sodium nitrate were imported from Norway, as against 730,939 tons received from Chile. Also 473.4 tons of ammonium nitrate were imported from Norway and 139.2 tons from Sweden, and 14,494 tons of calcium nitrate from Norway and r,033.6 tons from Sweden. New plants for extracting nitrogen from the air are in course of construction not only in Sweden and Norway, but also in Upper Bavaria, in the Tyrol, in Switzerland, and in the valley of the Rhine.

VoL. CLXXIV, No. 1042-30 